\title{
Liver metastasis originating from colorectal cancer with macroscopic portal vein tumor thrombosis: a case report and review of the literature
}

Yoshito Tomimaru ${ }^{1,2}$, Yo Sasaki ${ }^{3 *}$, Terumasa Yamada ${ }^{1}$, Kunihito Gotoh ${ }^{1}$, Shingo Noura ${ }^{1}$, Hidetoshi Eguchi ${ }^{1,2}$, Isao Miyashiro', Masayuki Ohue', Hiroaki Ohigashi', Masahiko Yano', Osamu Ishikawa', Shingi Imaoka'

\begin{abstract}
Introduction: Macroscopic tumor thrombi occupying the main portal branch are rarely seen in patients with liver metastasis.

Case presentation: A 55-year-old Japanese man who had previously undergone surgery for adenocarcinoma of the ascending colon presented with a metastatic liver tumor accompanied by a macroscopic tumor thrombus in the right portal branch. Right lobectomy and removal of the tumor thrombus were performed, and the liver metastasis and tumor thrombus were successfully resected. Histopathological examination of the liver tumor revealed adenocarcinoma, consistent with that of the previous colon cancer, confirming that the liver tumor was a metastasis from the colon cancer. Our patient remains well without recurrence at 51 months after the liver surgery.

Conclusion: The prognosis of patients with liver metastasis accompanied by a portal vein tumor thrombus remains unknown, but, considering several previous reported cases together with our case report, a better prognosis may be expected if the tumor is successfully removed by anatomical liver resection.
\end{abstract}

\section{Introduction}

Portal vein tumor thrombosis (PVTT) is associated with hepatocellular carcinoma (HCC), with a reported incidence of PVTT of $30 \%$ to $70 \%$ [1-3]. A recent pathological study of metastatic liver cancer originating from colorectal cancer found microscopic tumor invasion in the intra-hepatic portal vein to be a relatively common finding in addition to HCC $[4,5]$. However, macroscopic tumor thrombi occupying the main portal branch are rare in patients with liver metastasis [6,7], including that from colorectal cancer (Table 1) [8-14].

We report on a case of liver metastasis from colon cancer with macroscopic tumor thrombi in the right portal branch. Herein, we describe the case and review the literature for liver metastases from colorectal cancer

* Correspondence: yosasaki@hcn.zaq.ne.jp

${ }^{3}$ Department of Surgery, Yao Municipal Hospital, Osaka, Japan

Full list of author information is available at the end of the article accompanied by macroscopic portal vein tumor thrombi.

\section{Case presentation}

A 55-year-old Japanese man underwent a right hemicolectomy in our hospital for a tumor in the ascending colon.. He did not have any inherited or acquired thrombophilic predispositions. The tumor was histopathologically diagnosed as moderately differentiated adenocarcinoma, and staged as IIIB (T4N1M0), according to the TNM (tumor, nodes, metastasis) classification [15]. Tumor markers including carcinoembryonic antigen (CEA) and carbohydrate antigen 19-9 (CA19-9) were all within normal limits before the operation. During followup in our outpatient clinic, our patient received adjuvant systemic chemotherapy for six months.

Despite the adjuvant treatment, abdominal computed tomography (CT) 13 months after surgery showed a liver tumor in segment 8 based on Couinaud's classification [16]. Our patient was subsequently readmitted to 
Table 1 Previously reported cases with macroscopic portal vein thrombus (PVTT) from successfully resected colorectal cancers

\begin{tabular}{|c|c|c|c|c|c|c|c|c|c|c|c|c|}
\hline $\begin{array}{l}\text { Case } \\
\text { no. }\end{array}$ & Reference & $\begin{array}{l}\text { Age } \\
\text { and } \\
\text { gender }\end{array}$ & $\begin{array}{l}\text { Synchronous } \\
\text { or } \\
\text { metachronous }\end{array}$ & $\begin{array}{l}\text { Location of } \\
\text { primary } \\
\text { tumor }\end{array}$ & Histology & Stage & $\begin{array}{l}\text { Interval from colorectal } \\
\text { resection to diagnosis of } \\
\text { PVTT, months }\end{array}$ & $\begin{array}{l}\text { Size of liver } \\
\text { metastasis, } \\
\mathrm{mm}\end{array}$ & $\begin{array}{l}\text { Location of } \\
\text { liver } \\
\text { metastasis }\end{array}$ & $\begin{array}{l}\text { Location } \\
\text { of PVTT }\end{array}$ & $\begin{array}{l}\text { Survival after } \\
\text { removal of PVTT, } \\
\text { months }\end{array}$ & Prognosis \\
\hline 1 & $\begin{array}{l}\text { Tanaka } \\
\text { et al. [8] }\end{array}$ & $59 / \mathrm{M}$ & Synchronous & Sigmoid & Mod & T3N1 & - & Unknown & S8, left & Left PV & 11 & $\begin{array}{l}\text { Alive, } \\
\text { recurrence }\end{array}$ \\
\hline 2 & $\begin{array}{l}\text { Tanaka } \\
\text { et al. [8] }\end{array}$ & $54 / \mathrm{M}$ & Metachronous & Rectum & Mod & T4N2 & 12 & 70 & $S 2 / 3$ & Left PV & 21 & $\begin{array}{l}\text { Alive, no } \\
\text { recurrence }\end{array}$ \\
\hline 3 & $\begin{array}{l}\text { Tanaka } \\
\text { et al. [8] }\end{array}$ & $60 / \mathrm{M}$ & Metachronous & Transverse & Poor & T3N2 & 4 & 25 & S7 & Right PV & 31 & $\begin{array}{l}\text { Alive, no } \\
\text { recurrence }\end{array}$ \\
\hline 4 & $\begin{array}{l}\text { Tanaka } \\
\text { et al. [8] }\end{array}$ & $63 / F$ & Metachronous & Sigmoid & Well & T3NO & 47 & 55 & S6 & $\begin{array}{l}\text { Posterior } \\
\text { PV }\end{array}$ & 55 & $\begin{array}{l}\text { Alive, no } \\
\text { recurrence }\end{array}$ \\
\hline 5 & $\begin{array}{l}\text { Tanaka } \\
\text { et al. [8] }\end{array}$ & $62 / F$ & Metachronous & Descending & Mod & T3N1 & 11 & - & - & Right PV & 102 & $\begin{array}{l}\text { Alive, no } \\
\text { recurrence }\end{array}$ \\
\hline 6 & $\begin{array}{l}\text { Lee } \\
\text { et al. [10] }\end{array}$ & $28 / \mathrm{M}$ & Synchronous & Sigmoid & Muc & $\begin{array}{l}\text { Unknown } \\
(\mathrm{N}+)\end{array}$ & - & 40 & $S 2 / 3$ & $\begin{array}{l}\text { Left PV } \\
\text { branch }\end{array}$ & 1.5 & $\begin{array}{l}\text { Alive, } \\
\text { recurrence }\end{array}$ \\
\hline 7 & $\begin{array}{l}\text { Sugiura } \\
\text { et al. [11] }\end{array}$ & $39 / F$ & Metachronous & $\begin{array}{l}\text { Transverse, } \\
\text { rectum }\end{array}$ & Well & Unknown & 141 & $\begin{array}{l}\text { Unknown } \\
\text { (huge) }\end{array}$ & S4/5/6/7/8 & Left PV & 24 & $\begin{array}{l}\text { Alive, no } \\
\text { recurrence }\end{array}$ \\
\hline 8 & $\begin{array}{l}\text { Urahashi } \\
\text { et al. [12] }\end{array}$ & $57 / \mathrm{M}$ & Metachronous & Transverse & Mod & T3N1 & $<24$ & 40 & $56 / 7$ & Main PV & 11 & $\begin{array}{l}\text { Died, } \\
\text { recurrence }\end{array}$ \\
\hline 9 & $\begin{array}{l}\text { Urahashi } \\
\text { et al. [12] }\end{array}$ & $51 / \mathrm{M}$ & Metachronous & Transverse & Mod & T3N2 & $<24$ & 145 & $57 / 8$ & $\begin{array}{l}\text { Anterior } \\
\text { PV }\end{array}$ & 9 & $\begin{array}{l}\text { Died, } \\
\text { recurrence }\end{array}$ \\
\hline 10 & $\begin{array}{l}\text { Urahashi } \\
\text { et al. [12] }\end{array}$ & $54 / \mathrm{M}$ & Metachronous & Rectum & Well & T3N2 & $<24$ & 35 & S3 & Left PV & 36 & $\begin{array}{l}\text { Died, } \\
\text { recurrence }\end{array}$ \\
\hline 11 & $\begin{array}{l}\text { Urahashi } \\
\text { et al. [12] }\end{array}$ & 70/F & Metachronous & Ascending & Mod & T3N1 & $<24$ & - & - & Main PV & 6 & $\begin{array}{l}\text { Died, } \\
\text { recurrence }\end{array}$ \\
\hline 12 & $\begin{array}{l}\text { Urahashi } \\
\text { et al. [12] }\end{array}$ & $45 / F$ & Metachronous & Descending & Mod & T3N2 & $<24$ & 60 & S5, S6, S8 & Main PV & 10 & $\begin{array}{l}\text { Died, } \\
\text { recurrence }\end{array}$ \\
\hline 13 & $\begin{array}{l}\text { Oikawa } \\
\text { et al. [13] }\end{array}$ & $55 / F$ & Synchronous & Rectosigmoid & Muc & T3N1 & - & 100 & s6/7, left & $\begin{array}{l}\text { Posterior } \\
\text { PV }\end{array}$ & 9 & $\begin{array}{l}\text { Died, } \\
\text { recurrence }\end{array}$ \\
\hline 14 & $\begin{array}{l}\text { Matsumoto } \\
\text { et al. [14] }\end{array}$ & $58 / \mathrm{M}$ & Metachronous & Rectosigmoid & Mod & T3NO & 6 & - & - & Left PV & 66 & $\begin{array}{l}\text { Alive, no } \\
\text { recurrence }\end{array}$ \\
\hline 15 & $\begin{array}{l}\text { Present } \\
\text { case }\end{array}$ & $55 / F$ & Metachronous & Ascending & Mod & T4N1 & 13 & 28 & S8 & Right PV & 51 & $\begin{array}{l}\text { Alive, no } \\
\text { recurrence }\end{array}$ \\
\hline
\end{tabular}

Mod = moderately differentiated adenocarcinoma; poor $=$ poorly differentiated adenocarcinoma; PV = portal vein; PVTT = portal vein tumor thrombosis; well $=$ well differentiated adenocarcinoma; muc = mucinous adenocarcinoma. 
our hospital for full diagnosis and treatment of the liver tumor. Hepatitis B surface antigen, hepatitis B core antibody, and hepatitis $\mathrm{C}$ antibody test results were negative. Tumor markers including CEA, CA19-9, $\alpha$-fetoprotein, and protein induced by vitamin $\mathrm{K}$ absence or antagonist II, were all within normal limits. CT arteriography (CTA) showed a tumor of approximately 25 $\mathrm{mm}$ in diameter consisting of two components: an apparently solid part and a cystic component. The solid component of the tumor was enhanced in the early phase of the CTA and was washed out in the delayed phase, a pattern compatible with HCC (Figure 1A). However, based on the cystic component, the tumor was also suspected to be a cystadenocarcinoma. The right portal vein was not visible on portography, but CT during arterial portography (CTAP) revealed defective portal perfusion in the whole right lobe of the liver (Figure 1C). This finding was suggestive of PVTT. Endoscopic retrograde cholangiography was performed to differentiate cystadenocarcinoma connected to a biliary duct. However, no specific findings of biliary carcinoma were noted and the collected bile sample was cytologically negative. For preoperative differential diagnosis of the tumor, echo-guided biopsy was performed. The biopsy revealed that the liver tumor was a liver metastasis from the colon cancer. With a preoperative diagnosis of liver metastasis from colon cancer, laparotomy was performed. Neither peritoneal dissemination nor hilar lymph node metastasis was detected. The liver tumor, measuring $28 \times 25 \mathrm{~mm}$ in size, was located in segment 8 , while PVTT was located in the right portal vein in direct communication with the liver tumor. Our patient underwent a right lobectomy (Figure 2A). The resected tumor, which had a fibrotic capsule, macroscopically
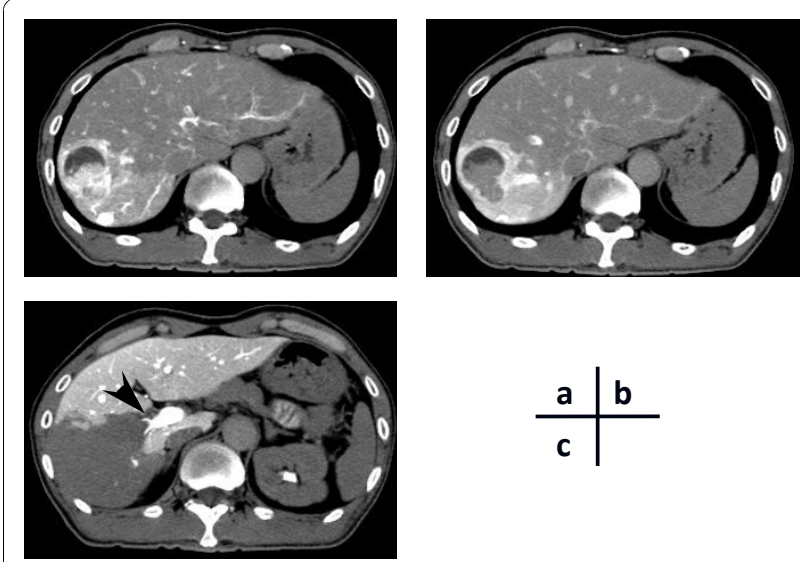

Figure 1 Computed tomography arteriography (CTA) of the liver tumor in the early phase (A) and the delayed phase (B).

C) Computed tomography during arterial portography (CTAP) showing a portal vein tumor thrombus (arrow) and a perfusion defect in the entire right lobe.

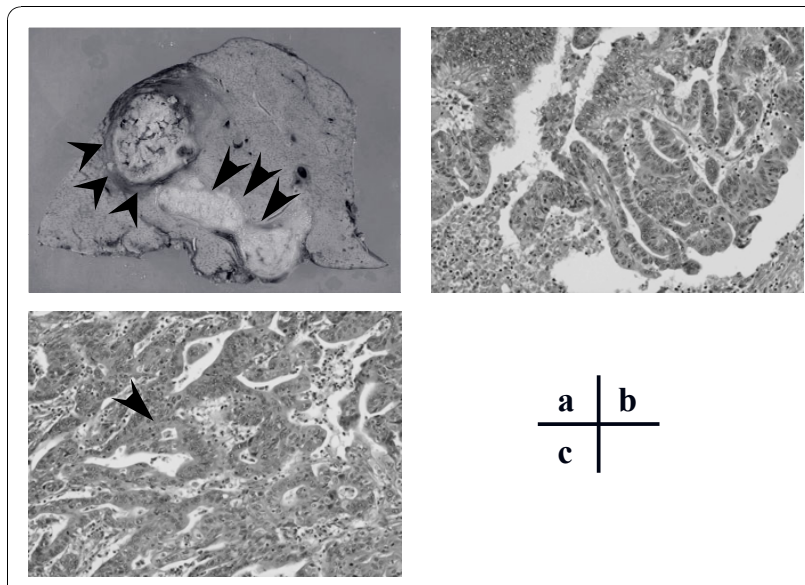

Figure 2 A) Macroscopic view of the resected liver including the metastatic liver tumor (arrowheads) and the tumor thrombus in the right portal vein (arrows). Histopathological findings of the metastatic liver tumor (B) and primary colon cancer (C) showing moderately differentiated adenocarcinoma.

resembled HCC. The cystic component observed on preoperative examination was not detected in the resected specimen. Histopathology of the resected liver tumor and PVTT revealed a moderately differentiated adenocarcinoma (Figure 2B). The histopathological findings from the resected tumor were similar to the previously resected ascending colon cancer. Based on the similarity, the final diagnosis for the liver tumor was a liver metastasis from the ascending colon cancer accompanied by macroscopic PVTT in the right portal branch. Histopathological infiltration into the endothelial layer of the portal vein was not seen. All resected margins were free from cancer. Postoperatively, our patient agreed to receive adjuvant chemotherapy. Our patient remains healthy, with no evidence of recurrence 51 months after the hepatectomy.

\section{Discussion}

Microscopic tumor invasion into the intra-hepatic portal vein is detected in about $20 \%$ of cases with liver metastasis from colorectal cancer [4]. However, our review of previously reported cases revealed few instances of PVTT in the main portal branch [8-14]. In fact, the reported incidence of macroscopic PVTT similar to that observed in our case report is $2.8 \%$ (4 of 142) [9]. From January 1990 to December 2008, 231 patients underwent resection of liver metastases from primary colorectal cancer in our hospital. Of these patients, only our patient's case showed macroscopic PVTT (0.4\%).

Macroscopic examination of the resected tumor in our patient did not show the preoperatively detected cystic component of the tumor. It is possible that necrotic fluid, having filled the cystic component, was absorbed 
and thus replaced by the tumor before removal. The resected liver tumor and PVTT macroscopically resembled HCC, which commonly develops tumor thrombi and expansive growth in the portal vein and in the hepatic vein [17]. The capsule formation of HCC is possibly the result of mechanical compression or high inner pressure from the expansive tumor growth, thus it is also feasible that tumor thrombi might extend into the portal vein via a pressure gradient mechanism [18]. In contrast, liver metastases from colorectal cancer are generally less commonly surrounded by a capsule compared to $\mathrm{HCC}$, with one study detecting encapsulated liver metastases from colorectal cancer in only $20 \%$ of cases [19]. The resected tumor in our patient, which was encapsulated, also resembled HCC in this point of the capsule formation. This resemblance to HCC may suggest that the PVTT in this case might have also expanded into the portal vein through a pressure gradient mechanism, as in HCC.

Table 1 summarizes 15 reported cases of liver metastasis from colorectal cancer with macroscopic PVTT, including our patient. No specific clinical features typified patients with colorectal liver metastasis and PVTT with respect to age, gender, or the primary tumor site. With regard to the stage of the primary colorectal cancer, all the primary colorectal lesions recorded were divided into T3 or T4 according to the TNM classification [15], and lymph node metastasis was found in most of the cases (12 of 14, 86\%). In 12 of the 15 cases (80\%), liver metastasis was accompanied by PVTT, and the liver tumor was relatively large $(60 \pm 37 \mathrm{~mm}$; range, 25 to $145 \mathrm{~mm}$ ). PVTT was found metachronously in 12 patients, and synchronously with the primary tumor in the remaining three patients. Although Matsumoto et al. [14] suggested that survival after the operation of PVTT from colorectal cancer might depend on whether the PVTT had developed synchronously or metachronously, this suggestion seems not to be applied to the review in the present study. With regards to the liver tumor, anatomical liver resection was performed in all 15 patients. The one-year, three-year and five-year overall survival rates in the 15 cases after operation for PVTT were $64.3 \%, 51.4 \%$, and $51.4 \%$, respectively. Since this analysis was performed only in a limited number of patients, specifically successful cases, the analysis did not allow a precise general prognosis to be determined for metastatic liver tumor with PVTT. However, even if the aforementioned success bias was taken into consideration, this outcome seems to be relatively good. In general, anatomical liver resection is not usually employed for colorectal liver metastasis in contrast to HCC [20-22]. However, considering that colorectal liver metastasis with PVTT is likely to spread along the portal tributaries as in $\mathrm{HCC}$, it may be speculated that anatomical liver resection, which is suitable for such liver metastasis, contributes to the favorable prognosis for colorectal liver metastasis with PVTT, as suggested by some investigators $[9,10,14]$. Today, some treatment options for colorectal liver metastasis have been established including surgery, ablation therapy, hepatic arterial infusion chemotherapy, and systemic chemotherapy, but there is no consensus for the treatment for colorectal liver metastasis accompanying PVTT. This successful case is not enough to conclude that surgery is the best treatment option for such liver metastasis, but we suggest at least that macroscopic PVTT is not a contraindication to liver surgery.

\section{Conclusion}

Our patient had a successfully resected liver metastasis from colorectal cancer with macroscopic PVTT. The prognosis of patients with such PVTT remains unclear, but from previous reports it would appear a better prognosis can be expected if the tumor is successfully resected by anatomical liver resection.

\section{Consent}

Written informed consent was obtained from the patient for publication of this case report and any accompanying images. A copy of the written consent is available for review by the Editor-in-Chief of this journal.

\section{Author details}

'Department of Surgery, Osaka Medical Center for Cancer and Cardiovascular Diseases, Osaka, Japan. ${ }^{2}$ Department of Surgery, Graduate School of Medicine, Osaka University, Osaka, Japan. ${ }^{3}$ Department of Surgery, Yao Municipal Hospital, Osaka, Japan.

\section{Authors' contributions}

YT researched the case, reviewed the literature, and was a major contributor to preparation of the manuscript. YS was responsible for the research and review. TY, KG, SN, HE, IM, and MO supported the preparation of the manuscript. $\mathrm{HO}, \mathrm{MY}, \mathrm{Ol}$, and $\mathrm{SI}$ prepared the final version of the manuscript. All the authors read and approved the final manuscript.

\section{Competing interests}

The authors declare that they have no competing interests.

Received: 6 April 2010 Accepted: 26 November 2010

Published: 26 November 2010

\section{References}

1. Albacete RA, Matthews MJ, Saini N: Portal vein thromboses in malignant hepatoma. Ann Intern Med 1967, 67:337-348.

2. Subramanyam BR, Balthazar EJ, Hilton S, Lefleur RS, Horii SC, Raghavendra BN: Hepatocellular carcinoma with venous invasion. Sonographic-angiographic correlation. Radiology 1984, 150:793-796.

3. Liver Cancer Study Group of Japan: Primary liver cancer in Japan. Clinicopathologic features and results of surgical treatment. Ann Surg 1990, 211:277-287.

4. Yamamoto J, Sugihara K, Kosuge T, Takayama T, Shimada K, Yamasaki S, Sakamoto M, Hirohashi S: Pathologic support for limited hepatectomy in the treatment of liver metastases from colorectal cancer. Ann Surg 1995, 221:74-78. 
5. Shirabe K, Takenaka K, Gion T, Fujiwara Y, Shimada M, Yanaga K, Maeda T, Kajiyama $K$, Sugimachi $K$ : Analysis of prognostic risk factors in hepatic resection for metastatic colorectal carcinoma with special reference to the surgical margin. Br J Surg 1997, 84:1077-1080.

6. Atri M, de Stempel J, Bret PM, Illescas FF: Incidence of portal vein thrombosis complicating liver metastasis as detected by duplex ultrasound. J Ultrasound Med 1990, 9:285-289.

7. Otani T, Usui H, Tsunoda-Shimizu H, Takada Y, Takanishi K, Minami T: A crescent-shaped sparing proximal to a liver tumor may indicate underlying portal tumor thrombus. Hepatogastroenterology 2003, 50:1631-1633.

8. Tanaka A, Takeda R, Mukaihara S, Hayakawa K, Takasu K, Terajima H, Yamaoka Y, Chiba T: Tumor thrombi in the portal vein system originating from gastrointestinal tract cancer. J Gastroenterol 2002, 37:220-228.

9. Tada K, Kokudo N, Seki M, Ueno M, Azekura K, Ohta H, Yamaguchi T, Matusbara T, Takahashi T, Nakajima T, Yanagisawa A, Muto T: Hepatic resection for colorectal metastasis with macroscopic tumor thrombus in the portal vein. World I Surg 2003, 27:299-303.

10. Lee KF, Chu W, Lai PB: Portal vein tumor thrombus in colorectal liver metastasis. Am J Surg 2005, 190:364-365.

11. Sugiura T, Nagino M, Ebata T, Arai T, Oda K, Yuasa N, Nimura Y: Treatment of colorectal liver metastasis with biliary and portal vein tumor thrombi by hepatopancreatoduodenectomy. J Hepatobiliary Pancreat Surg 2006, 13:256-259.

12. Urahashi T, Yamamoto M, Ohtsubo T, Katsuragawa H, Katagiri S, Takasaki K: Liver metastases with massive portal venous tumor thrombi from colorectal cancer: can be treated by surgical resection? Hepatogastroenterology 2007, 54:210-213.

13. Oikawa T, Takayama T, Okada S, Kamo T, Sugitani M, Sakamoto M: Macroscopic portal vein tumor thrombi of liver metastasis from colorectal cancer. J Hepatobiliary Pancreat Surg 2009, 16:90-93.

14. Matsumoto J, Kojima T, Hiraguchi E, Abe M: Portal vein tumor thrombus from colorectal cancer with no definite metastatic nodules in liver parenchyma. J Hepatobiliary Pancreat Surg 2009, 16:688-691.

15. Sobin LH, Wittekind C: UICC TNM Classification of Malignant Tumours. 5 edition. New York: Wiley; 1997, 66-69.

16. Couinaud C: Lobes et segments hepatiques. Press Med 1954, 62:709-712.

17. Nakashima T, Okuda K, Kojiro M, Jimi A, Yamaguchi R, Sakamoto K, Ikari T: Pathology of hepatocellular carcinoma in Japan. 232 Consecutive cases autopsied in ten years. Cancer 1983, 51:863-877.

18. Grigioni WF, D'Errico A, Biagini G, Mazziotti A, Bolondi L, Liotta LA Mancini AM, Garbisa S: The capsule surrounding primary liver tumors: wherefrom its prognostic significance? Int I Cancer 1990, 45:637-643.

19. Lunevicius R, Nakanishi H, Ito S, Kozaki K, Kato T, Tatematsu M, Yasui K: Clinicopathological significance of fibrotic capsule formation around liver metastasis from colorectal cancer. J Cancer Res Clin Oncol 2001, 127:193-199.

20. Makuuchi M, Hasegawa H, Yamazaki S: Ultrasonically guided subsegmentectomy. Surg Gynecol Obstet 1985, 165:346-350.

21. Minagawa M, Makuuchi M, Torzilli G, Takayama T, Kawasaki S, Kosuge T, Yamamoto J, Imamura H: Extension of the frontiers of surgical indications in the treatment of liver metastases from colorectal cancer: long-term results. Ann Surg 2000, 231:487-499.

22. Kokudo N, Tada K, Seki M, Ohta H, Azekura K, Ueno M, Matsubara T, Takahashi T, Nakajima T, Muto T: Anatomical major resection versus nonanatomical limited resection for liver metastases from colorectal carcinoma. Am J Surg 2001, 181:153-159.

doi:10.1186/1752-1947-4-382

Cite this article as: Tomimaru et al:: Liver metastasis originating from colorectal cancer with macroscopic portal vein tumor thrombosis: a case report and review of the literature. Journal of Medical Case Reports 2010 4:382.

\section{Submit your next manuscript to BioMed Central and take full advantage of:}

- Convenient online submission

- Thorough peer review

- No space constraints or color figure charges

- Immediate publication on acceptance

- Inclusion in PubMed, CAS, Scopus and Google Scholar

- Research which is freely available for redistribution

Submit your manuscript at www.biomedcentral.com/submit
Biomed Central 